\title{
Polysaccharide and extracts from Lentinula edodes: structural features and antiviral activity
}

\author{
Vinicius Pires Rincão ${ }^{1}$, Kristie Aimi Yamamoto ${ }^{1}$, Nágila Maria Pontes Silva Ricardo ${ }^{3}$, Sandra Aguiar Soares ${ }^{3}$, \\ Luzia Doretto Paccola Meirelles ${ }^{2}$, Carlos Nozawa ${ }^{1}$ and Rosa Elisa Carvalho Linhares ${ }^{1 *}$
}

\begin{abstract}
Background: Lentinula edodes, known as shiitake, has been utilized as food, as well as, in popular medicine, moreover, compounds isolated from its mycelium and fruiting body have shown several therapeutic properties. The aim of this study was to determine the antiviral activity of aqueous (AqE) and ethanol (EtOHE) extracts and polysaccharide (LeP) from Lentinula edodes in the replication of poliovirus type 1 (PV-1) and bovine herpes virus type 1 (BoHV-1).
\end{abstract}

Methods: The time-of-addition assay was performed at the times $-2,-1,0,1$ and $2 \mathrm{~h}$ of the infection. The virucidal activity and the inhibition of viral adsorption were also evaluated. Plaque assay was used to monitor antiviral activity throughout.

Results: The AqE and LeP were more effective when added at $0 \mathrm{~h}$ of infection, however, EtOHE was more effective at the times $1 \mathrm{~h}$ and $2 \mathrm{~h}$ of the infection. AqE, EtOHE and LeP showed low virucidal activity, and the inhibition of viral adsorption was not significant.

Conclusions: The results allowed us to conclude that AqE, EtOHE and LeP act on the initial processes of the replication of both strains of virus.

Keywords: Lentinula edodes, Antiviral activity, Poliovirus, Bovine herpesvirus

\section{Background}

Currently, there are a little more than 40 drugs approved for clinical use in the treatment of viral infections [1]. Studies regarding these drugs concentrated on synthetic products up to the end of the $80 \mathrm{~s}$, when natural compounds attracted attention because of their efficacy in the inhibition of viruses important for human and animal health [2]. Natural products are recognized by the pharmaceutical industry because of their wide structural diversity, as well as, variety of pharmacological activities [3]. Amongst the sources of natural compounds, the fungi, especially the basidiomycetes, have stimulated interest from investigators.

The basidiomycete Lentinula edodes (Berkeley) Pegler (Lentinus edodes), known as shiitake, an edible mushroom native of the East Asia, is valued for its nutritional

\footnotetext{
* Correspondence: relin@uel.br

'Departamento de Microbiologia, Universidade Estadual de Londrina, Rod.

Celso Garcia Cid., km 380, CEP: 86051-990, Londrina, Paraná, Brazil

Full list of author information is available at the end of the article
}

and medicinal properties and culinary and industrial applications [4]. Shiitake is the second most popular in the world [5] and in the last decades various compounds with therapeutic properties have been isolated from its mycelium and fruiting body. Some of these have been widely studied, for example, the polysaccharide lentinan which has demonstrated high immunopotentiating and antimetastasic activities [6,7], antitumor activity [8,9], antibacterial, antifungal and antidiabetic activities $[10,11]$, among others. However, few works have examined the antiviral activity of this basidiomycete [12-14].

Poliovirus is a non-enveloped virus with an icosahedral capsid symmetry, and a genome consisting of a positive single-stranded RNA. The virion is classified in the genus Enterovirus, belonging to the family Picornaviridae, which includes many other pathogens of great importance to humans and other animals [15]. Despite the efforts to eradicate the virus, there were 1352 reported cases of poliomyelitis in African and Asian countries in 2010 [16]. Bovine herpesvirus (BoHV) is an
C Biomed Central

(c) 2012 Rincão et al; BioMed Central Ltd. This is an Open Access article distributed under the terms of the Creative Commons Attribution License (http://creativecommons.org/licenses/by/2.0), which permits unrestricted use, distribution, and reproduction in any medium, provided the original work is properly cited. 
important pathogen for the cattle industry. Viron belongs to the subfamily Alphaherpesvirinae, family Herpesviridae [17], has a genome consisting of a linear double-stranded DNA within an icosahedral capsid, enclosed by an envelope. In order to reduce losses caused by BoHV, vaccines consisting of attenuated virus are being utilized with positive results. However, the control of infections is still difficult, due to the latency established by the virus after primary infection or after vaccination [18].

The basidiomycetes show various biological activities and low toxicity what make them a promising source of bioactive molecules. Therefore, the aim of this study was to determine the antiviral activity of aqueous and ethanol extracts and polysaccharide of Lentinula edodes in the replication of poliovirus and bovine herpesvirus.

\section{Methods \\ Cells and virus}

HEp-2 cell cultures (human larynx epithelial cells carcinoma-ATCC, CCL-23) were grown in Dulbecco's Modified Eagle Medium (DMEM) (Gibco-BRL, EUA*), supplemented with $10 \%$ fetal bovine serum $(*)$ and 2 mM glutamine (Sigma Chem. Co., EUA**), $100 \mu \mathrm{g} / \mathrm{ml}$ streptomycin $\left({ }^{* *}\right), 100 \mathrm{IU} / \mathrm{ml}$ penicillin $(* *)$ and $2.5 \mu \mathrm{g} /$ $\mathrm{ml}$ amphotericin B (Bristol Myers-Squibb, Brazil).

The poliovirus type $1(\mathrm{PV}-1)$, vaccinal strain, was obtained from the ATCC (ATCC, VR-58) and the bovine herpesvirus type $1(\mathrm{BoHV}-1)$ was supplied by DMVP-UEL, Brazil. Both strains were propagated in HEp-2 cells, and virus titers determined by plaque assay.

\section{Aqueous and ethanol extracts}

The aqueous extract (AqE) of Lentinula edodes (lineage IW) was obtained as follows. Ground basideocarp was resuspended with distilled water, heated at $60^{\circ} \mathrm{C}$ for $1 \mathrm{~h}$ and centrifuged at $3000 \times \mathrm{g}$ for $5 \mathrm{~min}$. The supernatant was pre-filtered and submitted to ultrafiltration in 0.2 $\mu \mathrm{m}$ pore size membrane, and stored at $-20^{\circ} \mathrm{C}$.

The ethanol extract (EtOHE) was prepared by dissolving ground basideocarp in $46 \%$ ethanol, at room temperature $\left( \pm 25^{\circ} \mathrm{C}\right)$. The extract was centrifuged at 3,000 $\times \mathrm{g}$ for $5 \mathrm{~min}$, and the supernatant was lyophilized. The lyophilized was resuspended in DMEM, submitted to ultrafiltration in $0.2 \mu \mathrm{m}$ pore size membrane, and stored at $-20^{\circ} \mathrm{C}$.

\section{Polysaccharide extraction and purification}

The polysaccharide from Lentinula edodes (LeP) was isolated as described by Gonzaga et al. [19]. Briefly, dried mushroom was dissolved at $5 \%(\mathrm{w} / \mathrm{w})$ in distilled water at $100^{\circ} \mathrm{C}$ during $5 \mathrm{~h}$. The suspension was centrifuged and clear colorless extract was neutralized to $\mathrm{pH} 7.0$ with 0.1 $\mathrm{N} \mathrm{NaOH}$. One percent $\mathrm{NaCl}$ was added and the extract submitted to polysaccharides precipitation with ethanol (5 vol ethanol:1 vol extract). After hydrogen peroxide/ ethanol treatment, precipitate was resubmitted to ethanol extraction. The precipitate washed with ethanol and acetone was dried at $40^{\circ} \mathrm{C}$, dissolved in distilled water, clarified by centrifugation and lyophilized.

\section{Cytotoxic assay}

The cytotoxicity of the test substances was performed by dimethylthiazolyldiphenyl tetrazolium bromide (MTT) kit $\left.{ }^{* *}\right)$. HEp-2 cells were grown in 96-well microplates and treated with varying concentrations of AqE (0.1-100 $\mathrm{mg} / \mathrm{ml})$, EtOHE (0.1-40 mg/ml) and LeP (0.25-6.0 mg/ $\mathrm{ml})$. After $72 \mathrm{~h}$ incubation, the test was carried out according to the manufacturer's recommendation. Under the same conditions, cells without treatment were used as control. The $50 \%$ cytotoxic concentration $\left(\mathrm{CC}_{50}\right)$ was determined as the concentration capable of reducing the optical density by $50 \%$ in comparison with the control. The $\mathrm{CC}_{50}$ was calculated by linear regression analysis of the dose-response curves generated.

\section{Plaque reduction assay}

The antiviral activity by plaque reduction assay was done according to Melo et al. [20] and used throughout. Briefly, HEp-2 cells were cultivated in 24-well plates at $37^{\circ} \mathrm{C}$ in $5 \%$ of $\mathrm{CO}_{2}$. After complete confluence, the cells were infected and treated with the substances accordingly. Cell cultures were overlaid with nutrient agarose and supplemented with antibiotic. For PV-1 experiments, nutrient agarose was added of $25 \mathrm{mM} \mathrm{MgCl}$. The plates were incubated inverted at $37^{\circ} \mathrm{C}$ in $5 \% \mathrm{CO}_{2}$, for $48 \mathrm{~h}$. The cells were fixed with $20 \%$ formalin, stained with $0.5 \%$ crystal violet, after removal of the nutrient agarose layer. Concomitantly, mock-infected cells were used as control. The percentage of viral inhibition (\% V.I.) was calculated by the formula: \% V.I. = $[1$ - (number of plaques in test $/$ number of plaques in virus control) $] \times 100$.

The $50 \%$ inhibitory concentration $\left(\mathrm{IC}_{50}\right)$ was determined as the concentration capable of reducing 50\% the number of plaques forming units (PFU) in relation to the controls. The $\mathrm{IC}_{50}$ was determined by linear regression analysis of the curves of viral inhibition, for each treatment.

The selectivity index (SI) was calculated as the ratio of $\mathrm{CC}_{50}$ and $\mathrm{IC}_{50}$.

Strains of PV-1 and BoHV-1 were submitted to the treatment with $1,000 \mathrm{U} / \mathrm{ml}$ and $10,000 \mathrm{U} / \mathrm{ml}$ human alfa-2 interferon (Meizler Com. Intern. SA, Brazil), respectively.

\section{Virucidal activity}

To evaluate the direct effect of the substances on viral particles, at varying concentrations, $10^{6} \mathrm{PFU} / \mathrm{ml}$ of $\mathrm{PV}-1$ 
and $10^{5} \mathrm{PFU} / \mathrm{ml}$ of $\mathrm{BoHV}-1$ were mixed with equal volumes of $\mathrm{AqE}$ (3.1, 6.3, 12.5 and $25 \mathrm{mg} / \mathrm{ml})$, EtOHE $(0.375,0.75,1.5$ and $3 \mathrm{mg} / \mathrm{ml})$ and LeP $(0.025,0.05,0.1$ and $0.2 \mathrm{mg} / \mathrm{ml}$ ) for $1 \mathrm{~h}$ at $37^{\circ} \mathrm{C}$ and inoculated in cell cultures.

\section{Time-of-addition assay}

The evaluation of the time-of-addition effect of the substances, at varying concentrations, was done as in Yang et al. [21]. Cells cultivated in 24-well plates were treated with concentrations of $\mathrm{AqE}(3.1,6.3,12.5$ and $25 \mathrm{mg} /$ $\mathrm{ml})$, EtOHE $(0.375,0.75,1.5$ and $3 \mathrm{mg} / \mathrm{ml}$ ) and LeP $(0.025,0.05,0.1$ and $0.2 \mathrm{mg} / \mathrm{ml})$, before $(-1 \mathrm{~h}$ and $-2 \mathrm{~h})$, during $(0 \mathrm{~h})$ and after $(1 \mathrm{~h}$ and $2 \mathrm{~h})$ infection.

\section{Viral adsorption assay}

The inhibition of the viral adsorption was carried out according to Zhu et al. [22]. Briefly, the cells cultivated in 24-well plates were infected with viral strains in the presence of the $\operatorname{AqE}(3.1,6.3,12.5$ and $25 \mathrm{mg} / \mathrm{ml})$, EtOHE $(0.375,0.75,1.5$ and $3 \mathrm{mg} / \mathrm{ml})$ and LeP $(0.025$, $0.05,0.1$ and $0.2 \mathrm{mg} / \mathrm{ml}$ ), and incubated at $4{ }^{\circ} \mathrm{C}$ in $5 \%$ $\mathrm{CO}_{2}$ for one $\mathrm{h}$. The cells were washed twice with PBS, and plaque reduction assay was performed after $48 \mathrm{~h}$.

\section{Statistics}

The data were analyzed by ANOVA followed by Student's $t$-test. Values were considered significant to $p \leq$ 0.05. All experiments were performed in triplicate.

\section{Results}

The polysaccharide isolated from Lentinula edodes contains high levels of $\beta$-D-glucan. The ${ }^{13} \mathrm{C}$ NMR spectrum is shown in Figure 1 and $\beta(1 \rightarrow 6)$ and $\alpha(1 \rightarrow 4)$ glucans configurations were identified in the spectrum. The chemical displacements characteristics of the carbons $\mathrm{C} 1$ to C6 of the glycosidic ring are presented in Table 1.

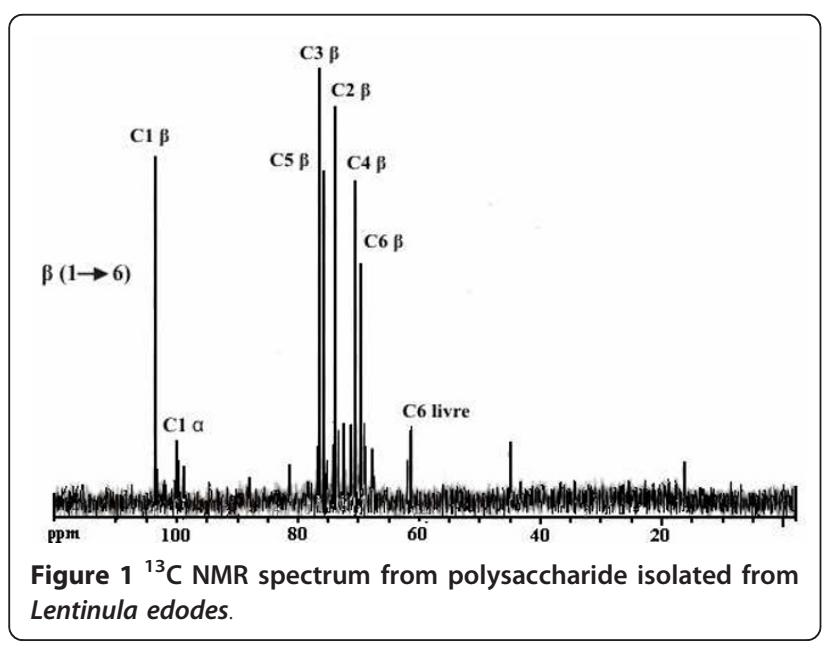

Table 1 Chemical displacements characteristics of $\beta(1 \rightarrow 6)$ and $\alpha(1 \rightarrow 4)$ glucans present in the purified polysaccharides isolated from Lentinula edodes

\begin{tabular}{ccccccc}
\hline Configurations & \multicolumn{6}{c}{ Chemical displacements $(\mathrm{ppm})$} \\
\cline { 2 - 7 } & C1 & C2 & C3 & C4 & C5 & C6 \\
\hline$\beta(1 \rightarrow 6)$ & 103.5 & 73.7 & 75.6 & 70.4 & 75.6 & 69.7 \\
\hline$\alpha(1 \rightarrow 4)$ & 99.9 & 72.4 & 76.4 & 81.3 & 71.1 & 61.6 \\
\hline
\end{tabular}

The cytotoxicity of the substances tested resulted in $\mathrm{CC}_{50}$ for the AqE, EtOHE and LeP of $74.0 \mathrm{mg} / \mathrm{ml}, 25.8$ $\mathrm{mg} / \mathrm{ml}$ and $4.0 \mathrm{mg} / \mathrm{ml}$, respectively (Table 2).

The results of antiviral activity for the AqE at different times of infection for PV-1 are shown in Figure 2a. When the $\mathrm{AqE}$ was added, one or two hours before infection (-1 $\mathrm{h}$ and $-2 \mathrm{~h}$ ), at the highest concentration tested $(25 \mathrm{mg} /$ $\mathrm{ml}$ ), there was an inhibition of $5.8 \%$ and zero\%, respectively. The addition of the extract at the concentrations of $3.1,6.3,12.5$ and $25 \mathrm{mg} / \mathrm{ml}$, at the moment of infection $(0 \mathrm{~h})$, resulted in a viral inhibition of $1.8,17.5,41.1$ and $82.5 \%$, respectively. However, for the time-of-addition of one hour post-infection ( $1 \mathrm{~h})$, at the same concentrations, the percentages of inhibition were 9.2, 12.1, 24.5 and $60.2 \%$, respectively. With the time-of-addition of two hours post-infection $(2 \mathrm{~h})$, the concentrations of $3.1 \mathrm{mg} /$ $\mathrm{ml}$ and $6.3 \mathrm{mg} / \mathrm{ml}$ were not effective, but, the concentrations of $12.5 \mathrm{mg} / \mathrm{ml}$ and $25 \mathrm{mg} / \mathrm{ml}$ inhibited the replication of PV-1 by 28.2 and $49.4 \%$, respectively.

The results of the tests for virucidal activity and the inhibition of adsorption showed that the AqE inhibited the replication of PV-1 by $38.3 \%$ and $19.0 \%$, respectively, at the highest concentration tested. Figure $2 \mathrm{~b}$ shows the results of the antiviral activity of $\mathrm{AqE}$ in the replication of BoHV-1. When the cells were treated with a concentration of $12.5 \mathrm{mg} / \mathrm{ml}$, the highest percentage of viral inhibition obtained was 19.1 and $4.2 \%$, for the times -1 $\mathrm{h}$ and $-2 \mathrm{~h}$ before the infection, respectively. At the time $0 \mathrm{~h}$, for the concentrations of 3.1, 6.3, 12.5 and $25 \mathrm{mg} /$ $\mathrm{ml}$ there was inhibition of 50.4, 43.3, 66.7 and 89.9\%, respectively. However, for post-infection treatments, at the same concentrations, there was inhibition of 20.4,

Table 2 Antiviral activity of aqueous extract (AqE), ethanol extract (EtOHE) and polysaccharide (LeP) of Lentinula edodes for poliovirus and bovine herpesvirus, monitored by plaque assay

\begin{tabular}{cccccc}
\hline Substances & $\mathbf{C C}_{50}{ }^{\mathbf{a}}$ & \multicolumn{2}{c}{ PV-1 } & \multicolumn{2}{c}{ BHV-1 } \\
\cline { 3 - 6 } & & $\mathbf{I C}_{\mathbf{5 0}}{ }^{\mathbf{b}}$ & $\mathbf{S I}^{\mathbf{c}}$ & $\mathbf{I C}_{\mathbf{5 0}}$ & SI \\
\hline AqE & 74.0 & 12.7 & 5.82 & 8.2 & 9.02 \\
\hline EtOHE & 25.8 & 1.30 & 19.85 & 2.13 & 12.11 \\
\hline LeP & $>4.0$ & 0.19 & $>21.33$ & 0.1 & $>39.21$
\end{tabular}

\footnotetext{
${ }^{a}$ Fifty percent cytotoxic concentration $(\mathrm{mg} / \mathrm{ml})$

${ }^{b}$ Fifty percent inhibitory concentration $(\mathrm{mg} / \mathrm{ml})$

c Selectivity index
} 


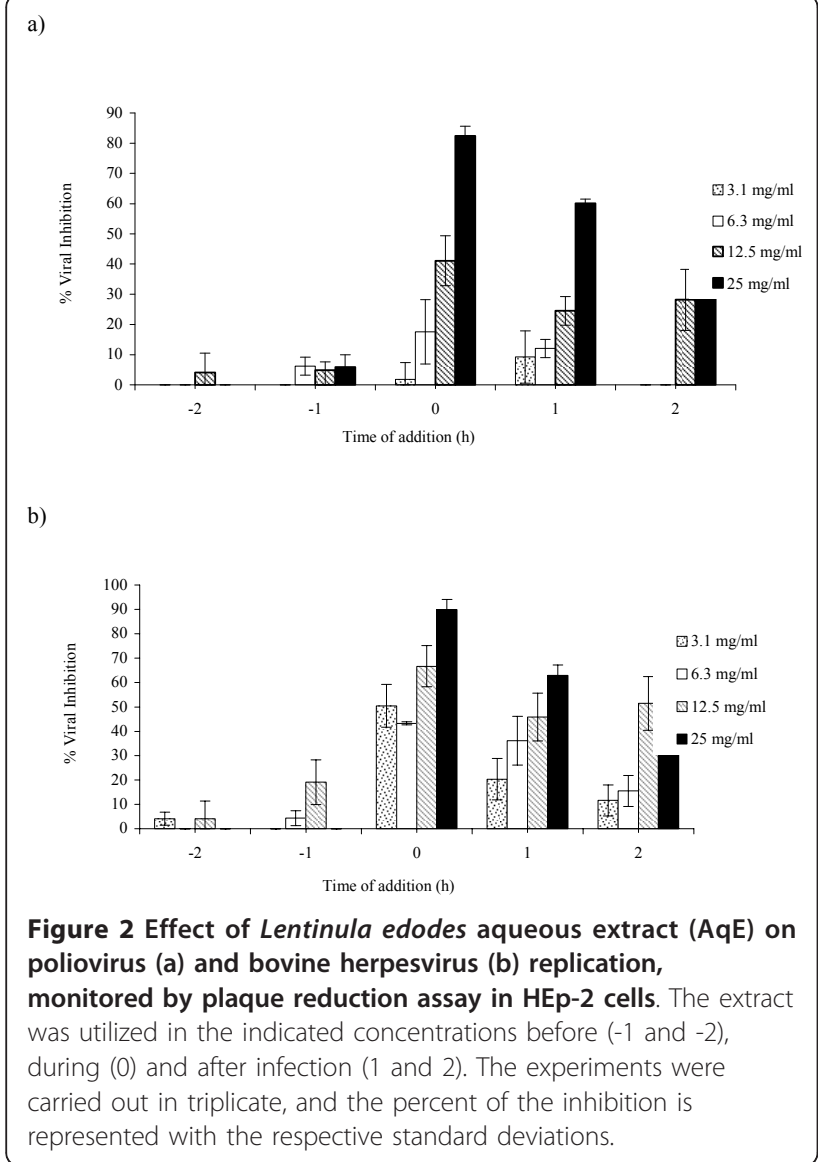

$36.1,45.8$ and $63.0 \%$ for the time $1 \mathrm{~h}$ and $11.7,15.5$, 51.5 and $75.7 \%$ for the time $2 \mathrm{~h}$.

For virucidal and inhibition of adsorption activities, there was a low inhibitory effect for the replication of BoHV-1 (32.1\% and zero\%, respectively) at the highest concentration of AqE.

The results of the EtOHE on the replication of PV-1 and BoHV-1 are shown in Figure 3. For PV-1, at concentrations of $0.375,0.75,1.5$ and $3 \mathrm{mg} / \mathrm{ml}$, the extract inhibited replication of the virus by zero, $45.7,56.5$ and $73.9 \%$, respectively, at time $0 \mathrm{~h}$ of infection (Figure 3a). When the extract was added at the times $1 \mathrm{~h}$ and $2 \mathrm{~h}$, at the indicated concentrations, the percentages of inhibition were $21.4,24.8,53.9$ and $76.9 \%$, and $20.7,36.3$, 70.8 and $94.6 \%$, respectively. However, treatments at times $-1 \mathrm{~h}$ and $-2 \mathrm{~h}$, showed no significant effect, with the highest inhibition of $21.7 \%$. In the replication of BoHV-1 (Figure 3b), at the same concentrations, the extract showed inhibition of zero, 10.2, 32.4 and 70.8\%, respectively, for the time $0 \mathrm{~h}$. Treatments at times $1 \mathrm{~h}$ and $2 \mathrm{~h}$ resulted in inhibition of 35.4, 46.9, 56.3 and $90.6 \%$, and, zero, 8.1, 22.3 and $47.6 \%$, respectively. The extract did not show any virucidal activity or inhibition of viral adsorption either for both virus strains.

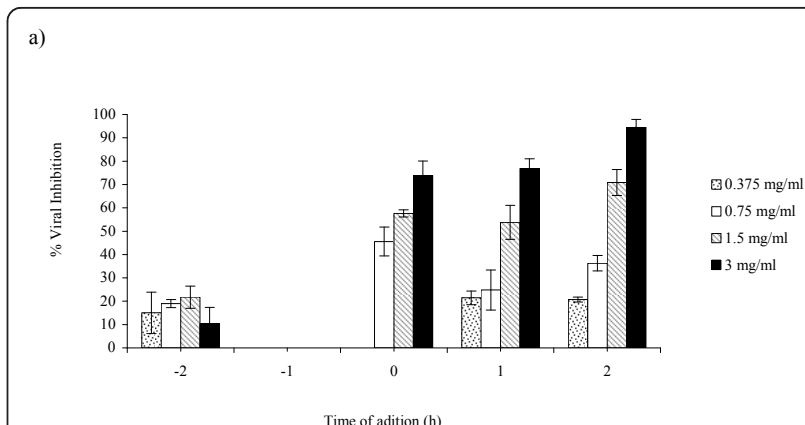

b)

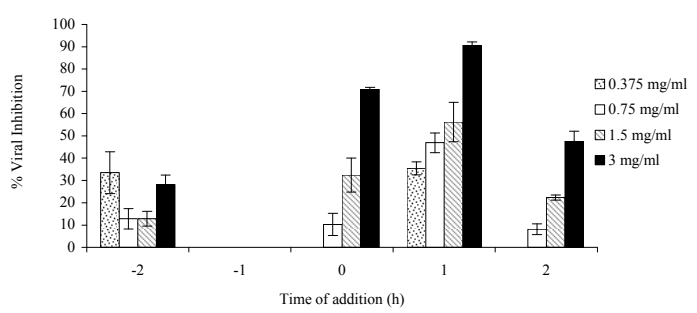

Figure 3 Effect of Lentinula edodes ethanol extract (EtOHE) on poliovirus (a) and bovine herpesvirus (b) replication, monitored by plaque reduction assay in HEp-2 cells. The extract was utilized in the indicated concentrations before (-1 and -2$)$, during (0) and after infection (1 and 2). The experiments were carried out in triplicate, and the percent of the inhibition is represented with the respective standard deviations.

The antiviral activity of LeP on the replication of PV-1 and BoHV-1 are shown in Figure 4. For PV-1, at the concentrations of $0.025,0.05,0.1$ and $0.2 \mathrm{mg} / \mathrm{ml}$, LeP inhibited viral replication by 11.2, 21.0, 23.6 and $63.8 \%$, respectively, at time $0 \mathrm{~h}$ of infection (Figure 4a). When the polysaccharide was added at time $1 \mathrm{~h}$, at the same concentrations, the percentages of inhibition were zero, 4.2, 2.0 and $28.5 \%$, respectively. However, for the treatments at the times $2 \mathrm{~h},-1 \mathrm{~h}$ and $-2 \mathrm{~h}$, no effect was observed. In the replication of BoHV-1, at the same concentrations, LeP showed inhibition of 23.1, 29.6, 37.1 and $74.2 \%$, respectively, for the time $0 \mathrm{~h}$ (Figure $4 \mathrm{~b}$ ). Treatments at the times $1 \mathrm{~h}$ and $2 \mathrm{~h}$ showed inhibition of $13.1,17.9,29.4$ and $33.5 \%$, and, zero, zero, 40.9 and $52.7 \%$, respectively.

The LeP virucidal activity on the PV-1 replication, at the same concentrations, showed inhibition of 14.5, 24.4, 28.5 and $34.3 \%$. However, LeP neither demonstrated virucidal activity for BoHV-1 nor inhibition of viral adsorption for both virus strains.

The $\mathrm{IC}_{50}$ and the respective SI for AqE, EtOHE and LeP, calculated for treatment at time $0 \mathrm{~h}$ of the infection, are shown in Table 2. 


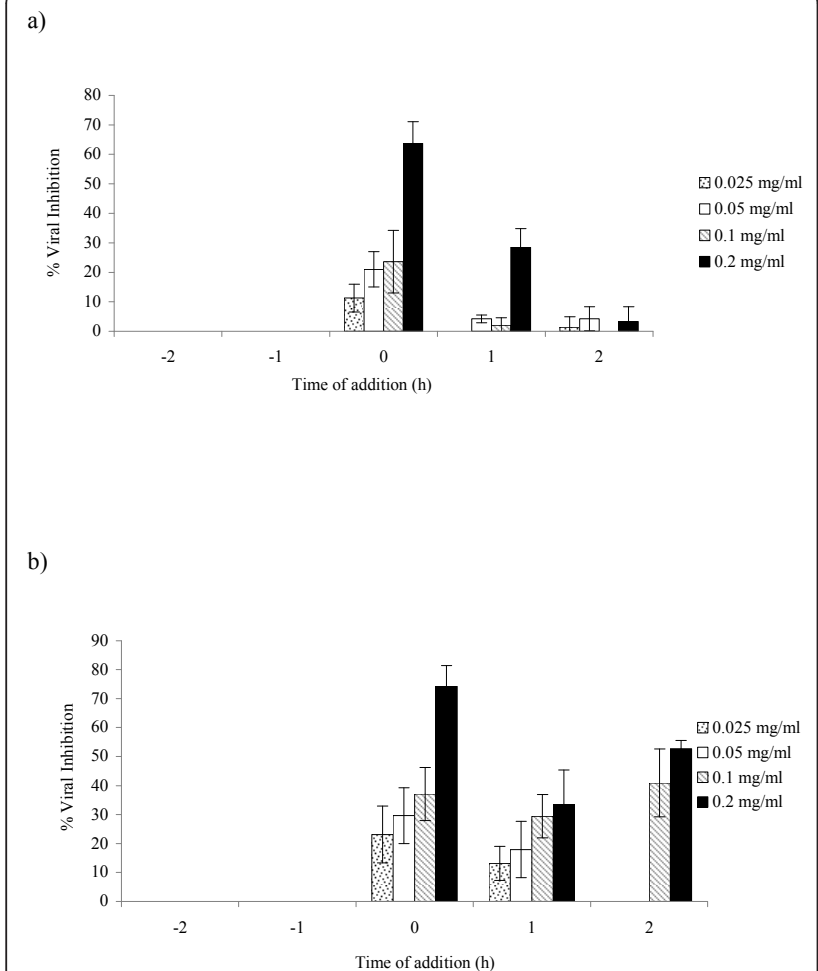

Figure 4 Effect of Lentinula edodes polysaccharide (LeP) on poliovirus (a) and bovine herpesvirus (b) replication, monitored by plaque reduction assay in HEp-2 cells. The extract was utilized in the indicated concentrations before $(-1$ and -2$)$, during ( 0 ) and after infection ( 1 and 2). The experiments were carried out in triplicate, and the percent of the inhibition is represented with the respective standard deviations.

Interferon alpha-2, used as positive control, inhibited the replication of PV-1 and BoHV-1 by $100 \%$ at concentrations of $1,000 \mathrm{U} / \mathrm{ml}$ and $10,000 \mathrm{U} / \mathrm{ml}$, respectively.

\section{Discussion}

In this work, the aqueous and ethanol extracts, and, polysaccharides of the fruiting body of Lentinula edodes were evaluated for antiviral activity.

The results demonstrated that both extracts, as well as, LeP, inhibited the replication of PV-1 and BoHV-1. AqE inhibited PV-1 and BoHV-1 in a dose-dependent curve and the highest percentages of inhibition were obtained at time $0 \mathrm{~h}$ of infection. No significant inhibitory effect was observed when the extract was added at $-1 \mathrm{~h}$ and $-2 \mathrm{~h}$ of the infection and for the inhibition of adsorption, for both virus. This may suggest that AqE did not influence significantly the specific binding of both virus to cell receptors. AqE did not show virucidal activity, and therefore, did not affect virus particle directly either. Sorimachi et al. [23] demonstrated that fractions of the aqueous extract of Agaricus blazei mycelium inhibited significantly the CPE of western equine encephalitis (WEE) virus, herpes simplex virus and poliovirus in Vero cells. This effect was observed after infection demonstrating that extract of basidiomycetes may contain inhibitory compounds for the initial phases of replication at least for herpesvirus and enterovirus. This finding strengthens the activity that we demonstrated of AqE on PV-1 and BoHV-1 replication.

EtOHE was effective in inhibiting the replication of both viruses. The greatest percent of viral inhibition was demonstrated when the extract was added post-infection, 94.6\% (2 h) and 90.6\% (1 h) for PV-1 and BoHV-1, respectively. It is likely, therefore, that EtOHE acted on the initial steps of the replication, considering that AqE did not show virucidal activity or inhibition of viral adsorption either. Awadh Ali et al. [24] demonstrated the presence of antiviral activity in ethanol extracts of the fruiting body and mycelium of Inonotus hispidus against influenza virus $A$ and $B$, attributing the effect to phenolic compounds. Concerning the relevance of glucan in biological activities it was demonstrated that LeP contains higher levels of $\beta$-D-glucan in comparison with an Agaricus blazei isolate [19]. In our study, the pronounced peak representative of anomeric carbon in $\beta$ $(1 \rightarrow 6)$ configuration is evidence of greater concentration of glucan in relation to that of the $\alpha$ configuration. Many studies disclose $\beta(1 \rightarrow 3)$ configuration for the isolated glucan from Lentinus edodes [25,26], therefore, being different to the one disclosed in this study. Certainly, the characteristics of the cultivation region, such as climate and growth conditions, justify such behaviour. LeP, a $\beta$-glucan-protein with a predominance of $\beta-1-6$, also showed a dose-dependent inhibitory effect on BoHV-1 and PV-1, although less pronounced, nevertheless, with a higher SI and lower $\mathrm{IC}_{50}$, compared to $\mathrm{AqE}$ and EtOHE extracts. The antiviral activity of extracts isolated from the basidiomycetes seems to be mostly attributed to the presence of polysaccharides. The anionic feature of the molecules can interfere with early stages of viral replication $[27,28]$ and sulfated polysaccharides demonstrate higher antiviral activity on enveloped virus [29].

\section{Conclusions}

In conclusion, we suggest that AqE, EtOHE and LeP act on the initial processes of PV-1 and BoHV-1 replication. The extracts and the polysaccharide could be considered as a source of potential antiviral substances. However, further study is necessary to better understanding of the step(s) of viral replication where inhibition occurs.

\section{Acknowledgements}

This work was partially supported by CNPq, CAPES and Fundação Araucária, and it is part of VPR M.Sc. manuscript. 


\section{Author details}

'Departamento de Microbiologia, Universidade Estadual de Londrina, Rod. Celso Garcia Cid., km 380, CEP: 86051-990, Londrina, Paraná, Brazil. ${ }^{2}$ Departamento de Biologia Geral, Universidade Estadual de Londrina, Rod. Celso Garcia Cid., km 380, CEP: 86051-990, Londrina, Paraná, Brazil. ${ }^{3}$ Departamento de Química Orgânica e Inorgânica, Universidade Federal do Ceará, Av. da Universidade, 2853, CEP: 60455-760, Fortaleza, Ceará, Brazil.

\section{Authors' contributions}

VPR participated in the studies on cytotoxicity and antiviral activity of the polysaccharide and extracts from Lentinula edodes and prepared the draft of the manuscript. KAY prepared the extracts and fractions and participated in the studies on antiviral activity. NMPSR and SAS participated in the extraction and purification of the polysaccharide, and participated in the manuscript. LDPM was responsible for shiitake cultivation and preparation of the extracts. RECL and CN were responsible for the design and coordination of the work, data analysis and manuscript writing and revision. All authors read and approved the final manuscript.

\section{Competing interests}

The authors declare that they have no competing interests.

Received: 30 November 2010 Accepted: 15 February 2012

Published: 15 February 2012

\section{References}

1. De Clercq E, Field HJ: Antiviral prodrugs-the development of successful prodrug strategies for antiviral chemotherapy. Br J Pharmacol 2006, 147:1-11.

2. Jones PS: Strategies for antiviral drug discovery. Antivir Chem Chemother 1998, 9:283-302.

3. Strohl WR: The role of natural products in a modern drug discovery program. Drug Discov Today 2000, 5:39-41.

4. Jiang T, Luo S, Chen Q, Shen L, Ying T: Effect of integrated application of gamma irradiation and modified atmosphere packaging on physicochemical and microbiological properties of shiitake mushroom (Lentinus edode). Food Chem 2010, 122:761-767.

5. Sugui MM, De Lima PLA, Delmanto RD, Da Eira AF, Salvadori DMF, Ribeiro LR: Antimutagenic effect of Lentinula edode (BERK.) Pegler mushroom and possible variation among lineages. Food Chem Toxicol 2003, 41:555-560.

6. Kupfahl C, Geginat $\mathrm{G}$, Hof H: Lentinan has a stimulatory effect on innate and adaptive immunity against murine Listeria monocytogene infection. Int Immunopharmacol 2006, 6:686-696.

7. Suzuki M, Takatsuki F, Maeda YY, Hamuro J, Chihara G: Antitumor and immunological activity of Lentinan in comparision with LPS. Int J Immunopharmacol 1994, 16:463-468.

8. Maruyama S, Sukekawa Y, Kaneko Y, Fujimoto S: Anti-tumor activities of lentinan and micellapist in tumor-bearing mice. Gan To Kagaku Ryoho 2006, 33:1726-1729.

9. Zhang L, Li X, Xu X, Zeng F: Correlation between antitumor activity, molecular weight, and conformation of lentinan. Carbohydr Res 2005, 340:1515-1521.

10. Jong SC, Birmingham M: Medicinal and therapeutic value of the shiitake mushroom. Adv Appl Microbiol 1993, 39:153-184.

11. Markova N, Kussovski V, Drandarska I, Nikolaeva S, Georgieva N, Radoucheva T: Protective activity of Lentinan in experimental tuberculosis. Int Immunopharmacol 2003, 3:1557-1562.

12. Kaneko Y, Chihara G: Potentiation of host resistance against microbial infections by Lentinan and its related polysaccharides. In Microbial Infections. Edited by: Friedman H et al. New York: Plenum; 1992:201-206.

13. Sasaki SH, Linhares REC, Nozawa CM, Montalván R, Paccola-Meirelles LD: Strains of Lentinula edode suppress growth of phytopathogenic fungi and inhibit Alagoas serotype of vesicular stomatitis virus. Braz J Microbiol 2001, 32:52-55.

14. Wang S, Welte T, Fang $\mathrm{H}$, et al: Oral Administration of Active Hexose Correlated Compound Enhances Host Resistance to West Nile Encephalitis in Mice. J Nutr 2009, 139:598-602.

15. Racaniello VR: One hundred years of poliovirus pathogenesis. Virology 2006, 344:9-16.
16. World Health Organization (WHO): Global polio eradication initiative. http://www.polioeradication.org/Dataandmonitoring/Poliothisweek.aspx. Accessed 26 dec 2011.

17. Jones $C$, Geiser $V$, Henderson $G$, et al: Functional analysis of bovine herpesvirus 1 (BHV-1) genes expressed during latency. Vet Microbiol 2006, 113:199-210.

18. Hurk SDL, Loehr Bl, Babiuk LA: Immunization of livestock with DNA vaccines: current studies and future prospects. Vaccine 2001, 19:2474-2479.

19. Gonzaga MLC, Ricardo NMPS, Heatley F, Soares SA: Isolation and characterization of polysaccharides from Agaricus blaze Murill. Carbohydr Polym 2005, 60:43-49.

20. Melo FL, Benati FJ, Roman WA Jr, Mello JCP, Nozawa C, Linhares REC: The in vitro antiviral activity of an aliphatic nitrocompound from Heteropteris aphrodisiac. Microbiol Res 2008, 163:136-139.

21. Yang CM, Cheng HY, Lin TC, Chiang LC, Lin CC: Acetone, ethanol and methanol extracts of Phyllanthus urinari inhibit HSV-2 infection in vitro. Antiviral Res 2005, 67:24-30.

22. Zhu W, Chiu LCM, Ooi VEC, Chan PKS, Ang PO Jr: Antiviral property and mode of action of a sulphated polysaccharide from Sargassum paten against herpes simplex virus type 2. Int J Antimicrob Agents 2004, 24:81-85.

23. Sorimachi $K$, Ikehara $Y$, Maezato $G$, et al: Inhibition by Agaricus blaze Murrill fractions of cytopathic effect induced by Western Equine Encephalitis (WEE) Virus on VERO cells in vitro. Biosci Biotechnol Biochem 2001, 65:1645-1647.

24. Awadh Ali NA, Mothana RAA, Lesnau A, Pilgrim H, Lindesquist U: Antiviral activity of Inonotus hispidu. Fitoterapia 2003, 74:483-485.

25. Surenjav $U$, Zhang $L, X u X$, Zhang $X$, Zeng F: Effects of molecular structure on antitumor activities of $(1 \otimes 3)$-d-glucans from different Lentinus Edode. Carbohydr Polym 2006, 63:97-104.

26. Zhang Y, Li S, Wang X, Zhang L, Cheung PCK: Advances in lentinan: Isolation, structure, chain conformation and bioactivities. Food Hydrocolloid 2011, 25:196-206.

27. Eo SK, Kim YS, Oh KW, Lee CK, Lee YN, Han SS: Mode of Antiviral Activity of Water Soluble Components Isolated from Elfvingia applanat on Vesicular Stomatitis Virus. Arch Pharm Res 2001, 24:74-78.

28. Kabanov A, Sementsova AO, Skarnovich MO, Teplyakova TV, Shishkina LN, Sergeev NA: Development of new effective antiinfluenza drugs based on extracts of basidiomycetes. Int J Infect Dis 2010, 14:(Suppl 1):e88.

29. Damonte EB, Matulewicz MC, Cerezo AS: Sulfated seaweed polysaccharides as antiviral agents. Curr Med Chem 2004, 11:2399-2419.

doi:10.1186/1743-422X-9-37

Cite this article as: Rincẫo et al:: Polysaccharide and extracts from Lentinula edodes: structural features and antiviral activity. Virology Journal 2012 9:37.

\section{Submit your next manuscript to BioMed Central and take full advantage of:}

- Convenient online submission

- Thorough peer review

- No space constraints or color figure charges

- Immediate publication on acceptance

- Inclusion in PubMed, CAS, Scopus and Google Scholar

- Research which is freely available for redistribution

Submit your manuscript at www.biomedcentral.com/submit
Ciomed Central 